\title{
RETENTION AND ENGAGEMENT OF GENERATION Y ENGINEERS
}

\author{
Miehe Marais \\ University of South Africa, Pretoria, South Africa \\ Antoni Barnard \\ University of South Africa, Pretoria, South Africa \\ Cebile Mensele \\ University of South Africa, Pretoria, South Africa
}

\begin{abstract}
This hermeneutic phenomenological study explored the retention and engagement of Generation $Y$ engineers in South Africa. In-depth interviews were conducted with six Generation Y engineers and data were analysed through interpretive phenomenological analysis. Findings demonstrate that hygiene retention factors are fundamental to engagement even though such factors do not enhance engagement. Generation $Y$ engineers ascribe to task and work setup engagement, yet their retention behaviour is ultimately directed by their career engagement. Organisations wanting to retain Generation $Y$ engineers should focus on hygiene factors, task and work-setup engagement as well as career engagement.
\end{abstract}

Keywords: Generation $Y$ engineers, retention, work engagement, hermeneutic phenomenology, interpretive phenomenological analysis

\section{Introduction}

In South Africa, as in other countries, retaining young talent is challenging because of skills shortages, employee mobility and the imminent retirement of Baby Boomers (Masibigiri \& Nienaber, 2011; Robyn \& Du Preez, 2013). The transfer of professional skills and knowledge

Contact: barnaha@unisa.ac.za. The authors declare that they have no relevant or material financial interests that relate to the research described in this paper. Also, the authors declare that the submitted paper is their original work and that, upon publication, nothing contained in it will not constitute an infringement of any copyright. Paper received 03.05.2017. Approved 30.06.2017. This paper is licensed under the Creative Commons Attribution-Non Commercial-No Derives 3.0. License. This paper is published with Open Access at www.socioeconomica.info. 
constitutes a threatening crisis as ageing generational cohorts continue to leave the workforce (National Planning Commission, 2011; Kultalahti \& Viitala, 2014; Robyn \& Du Preez, 2013). For organisations the retention of high performers and key employees with scarce and critical skills such as Generation Y engineers, is a business imperative (Allen, Bryant \& Vardaman, 2010; Aruna \& Anitha, 2015). In South Africa, engineering has been listed as a national scarce and critical skill (Department of Home Affairs, 2009). A demand for over 5000 engineers has been listed on the Department for Higher Education and Training's (DHET) 2012-13 skills demand list (DHET, n.d). Consulting Engineers South Africa (2012) reported that in June 2012, $86.5 \%$ of firms indicated a drive to increase their engineering staff, but were struggling to find suitable candidates as this country only has one engineer for every 3166 people. The demand for engineering skills are set against the significant contribution that engineers make towards socioeconomic development on all levels of a society as they impact on improved healthcare, housing, nutrition, transport, communications, and many other socio-economic benefits (UNESCO, 2010).

Retention of Generation $\mathrm{Y}$ engineers is dependent on maintaining their level of engagement to prevent them leaving the company and to ensure business success (Kennedy \& Daim, 2010). The importance of engagement in retaining employees is an established notion that organisations need to take note of (Schaufeli \& Bakker, 2004; Van Schalkwyk, Du Toit, Bothma \& Rothmann, 2010). Although work-related engagement is coupled with many positive organisational outcomes, increased job performance is especially significant (Bakker, Albrecht \& Leiter, 2011; Bakker \& Bal, 2010) in the knowledge economy, which is driven by intense competition (Bakker \& Schaufeli, 2008). In this economy there is a need for the maximised inputs associated with engaged workers who are energetic, dedicated and absorbed by their work (Bakker \& Schaufeli, 2008; Rothman \& Rothman, 2010).

Some studies have shown that Generation $\mathrm{Y}$ engineers act differently to other generational cohorts, with regard to their turnover behaviour (Karlsson, 2008; Rose \& Gordon, 2010) although some also found no distinctive differences (Vieira, 2010). To determine Generation Y work preferences, most studies employ a quantitative approach (Puybaraud, 2010; Talent Edge 2020, 2012; Robyn \& Du Preez, 2013). As such, explorative research to identify factors potentially important to understand the engagement and retention of engineers in South Africa has been called for (Wright, 2007; Kennedy \& Daim, 2010). The study objective here was therefore to explore the lived work experiences of Generation Y engineers in a South African work context in order to gain a better understanding of their retention and engagement behaviour. This study is important because it provides insight into the lived work experience of Generation Y engineers in South Africa and how organisations can harness their engagement and retain talent. The article is structured to first provide a conceptual background on generational theory, work retention and engagement with specific reference to research trends with regard to generation $\mathrm{Y}$ engineers. A description of the research methodology follows and the findings are presented from an interpretative phenomenological analysis perspective. 
Socioeconomica - The Scientific Journal for Theory and Practice of Socio-economic Development 2016, 5(10): 153-170

\section{Generational theory}

Interest in generational differences has its roots in ancient Greece (Burnett, 2011; Nash, 1978), with Karl Mannheim's (1952) pivotal contribution highlighting the sociological significance of differences in generations (Joshi, Dencker \& Franz, 2011). Schuman and Scott (1989) highlighted the dynamic of 'collective memories' that are distinctive of the tendency of people in a particular generational cohort to recall different events with formative experiences. Strauss and Howe (cited in Papenhausen, 2011) moved to popularise the concept of generations, offering a comprehensive theory to explain the concept of generations based on a cyclical theory of history and generations.

According to Constanza, Badger, Fraser, Severt and Gade (2012), there are some consistencies across the conceptualisations of generations. The authors define a generation as a group of people, about the same age, whose experiences are influenced by the same set of significant historical events that where experienced during key developmental periods in their lives, typically late childhood, adolescence and early adulthood. Despite conceptual and methodological disagreements in generational literature (Rosow, 1978; Ryder, 1965) the concept of generations remains an interesting subject of popular culture and media, and academic interpretations of this construct in the work context are becoming more sophisticated (Joshi et al., 2011; Jones \& Czerniewicz, 2010). Hillman (2014) highlights the four generational cohorts that have typically been identified in research as permeating the current workforce, namely the Traditionalists (employees born between 1922 and 1946), Baby Boomers (those employees born between 1946 and 1964), Generation Xers (employees born between 1964 and 1980) and the Generation Y employees, born between 1980 and 2000, and the focus of this study. Generation Y employees are also typically referred to as the Millennials, the Dot com generation, the Sunshine generation (Aruna \& Anitha, 2015) or to the iGeneration and the Generation Whine (Moss \& Martins, 2014). Members of a certain generation are said to have similar personalities, values, expectations, attitudes and lifestyle preferences (Bogdanowicz \& Bailey, 2002; Kowske, Rasch, \& Wiley, 2010; Schuman \& Scott, 1989) and which are brought into the workplace with them (Zemke, 2001) resulting in forming a distinct employee sub culture (Moss \& Martins, 2014). A typical Generation Y employee is for example said to value work-life balance (Gilbert, 2011; Lieber, 2010), training and development (PriceWaterhouseCoopers, 2009), the need for immediate feedback (Hershatter \& Epstein, 2010), prefers a direct communication style (Irvine, 2010), teamwork (Deloitte, 2009) and collaboration (Irvine, 2010; Myers \& Sadaghiani, 2010).

\section{Work retention}

Work retention refers to the initiatives an employer implements to encourage qualified and productive workers to continue working for the company and has the main objective of reducing unwanted voluntary turnover among valuable individuals in the company (Schuler \& Jackson, 2006). The turnover, retention and career behaviour of workers are significantly influenced by the knowledge economy and the resulting boundaryless organisation and 
boundaryless career (Arthur, Khapova \& Wildercom, 2005). To reduce the ever increasing costs of pension and medical benefits and to better adapt to the changing world of work, companies are replacing permanent employees with part-time workers and flattening company hierarchies (Feldman \& Ng, 2007). The talent pool has become global due to technological advances in that knowledge workers, particularly those with scarce and critical skills are mobile and sought after by competitors (Khapova, 2006). These changes have increased the complexity and challenge companies face with regard to the turnover and retention of critical skills. In South Africa, Sutherland and Jordaan (2004) studied the retention of knowledge workers (as which engineers are classified) and found that theories such as the belief that job satisfaction and organisational commitment lead to workers' loyalty (intention to remain with an employer) to a company may no longer hold true.

\section{Work-related engagement}

Engagement is associated with many positive outcomes for companies such as increased job performance, motivation, job satisfaction, increases in working safely, client satisfaction, return on assets and increased profits (Bakker, Demerouti \& Schaufeli, 2003; Bakker, Schaufeli, Leiter \& Taris, 2008; Harter, Schmidt \& Hayes, 2002; Park \& Gursoy, 2012; Schaufeli \& Bakker, 2004). Various types of work-related engagement have been distinguished (Anthony-McMann, Ellinger, Astakhova \& Halbesleben, 2016), including job engagement, organisational engagement, personal engagement, work engagement, employee engagement and career engagement (Du Plooy \& Roodt, 2010; Hirschi, \& Freund, 2014; Neault, \& Pickerell, 2011; Saks \& Gruman, 2014; Simpson, 2009). As these distinctive types of engagement differ in their respective antecedents and consequences, it is important to differentiate between them (Saks, 2006; Simpson, 2009) to curb confusion when researching the phenomenon (Anthony-McMann, et al., 2016; Schaufeli \& Bakker, 2010). In this study 'engagement' is regarded as encapsulating the relationship of the employee with his or her work, occupation and organisation.

Research conducted on Generation Y engineers shows that learning and development and support in terms of learning and development are very important. The engineers in these studies want to be given opportunities to develop (Karlsson, 2008; Wright, 2007), be learning in a learning organisation (Gruber, 2008), be trained, be mentored, manage their own career development (Vieira, 2010), have good career prospects (Wright, 2007) and have a say in their training (Rahaman, 2012). They also want to be challenged in their work (Gruber, 2008; Karlsson, 2008) and have opportunities for mental work (Karlsson, 2008). They assess practical work experience as valuable, value involvement in engineering design (Vieira, 2010) and have a high regard for exposure to leading technologies and global experience (Wright, 2007). They want to view the work that they are doing at present as what they want to do in the future (Karlsson, 2008). Autonomy is important (Gruber, 2008), particularly in terms of discerning their own work performance and being part of the decision-making process in terms of performance 
Socioeconomica - The Scientific Journal for Theory and Practice of Socio-economic Development 2016, 5(10): 153-170

appraisals, which will have a direct impact on their careers (Karlsson, 2008; Rahaman, 2012). Attaining work-life balance (Vieira, 2010; Wright, 2007) and being able to satisfy higher order needs outside work are key (Gruber, 2008). These engineers also see receiving a favourable total financial package as important (Wright, 2007). Lastly, they value making a contribution, making a difference (Vieira, 2010) and having corporate culture and values aligned to their own (Gruber, 2008).

\section{Research methodology}

This qualitative exploratory study was approached from a hermeneutic phenomenological perspective as developed in the writings of Heidegger and Ricoeur (Lindseth \& Norberg, 2004). Choosing a qualitative methodology allowed a holistic exploration of the lived work experiences of Generation Y engineers in their natural context, in depth and with interactive openness (Durrheim, 2007). Applying a hermeneutic phenomenological approach as framed by Heidegger's philosophy, allows for the notion that our understanding of the world is interpretative and relative, and that our interpretation of the life world is impacted on by our preconceptions, prior knowledge and experiences (Dahlberg, Dahlberg \& Nyström, 2007). The findings presented here do therefore not claim a specific or objective knowledge, but presents a perspective on Generation Y engineers' retention and engagement dynamics.

\subsection{Procedure}

This research was guided by the rules of ethical conduct as prescribed in the Health Professions Act 56 of 1974, as well as the ethics policy of the University of South Africa (UNISA). Ethical clearance to conduct this study was provided by the Ethics Committee of the College of Economic and Management sciences at UNISA. Written informed consent to participate in the research and to have the interviews digitally recorded, was obtained from each participant before commencing with the interviews. The participants were assured that the information they provided would be kept confidential and no personal identifiable details would be included in any of my research reports. Both the transcriber and the professional language practitioner signed confidentiality forms prior to engaging with the data. Codes were assigned as identifiers to each participant to ensure anonymity of data and data were electronically stored as password protected files. All hard copy data were destroyed.

\subsection{Participants}

Through purposeful and snowball sampling 6 engineers working in Gauteng and Mpumalanga across the fields of mechanical, process, electrical or industrial engineering, were identified to participate in the study. The sample size is appropriate as small sample sizes are appropriate to hermeneutic phenomenological research which focus on in-depth analysis of life 
world phenomena, rather than generalisation to a broader population (Brocki \& Wearden, 2006). Engineers born between 1981 and 1993 were included in this study, to cater for those in the transition generation, which forms part of Generation Y in South Africa (Deal et al., 2012) and is aligned with the European and American distinction of Generation Y (see Robyn, 2012). Participants working for at least 2 years in the profession were sought. Table 1 below summarises the demographic and industry profile of the participants. The sample included 2 females ( 1 white and 1 Indian) and four males ( 3 white and 1 black) between the ages of 25 and 30 years. Participants were mainly employed in the petrochemical and consulting industries and functioned in either a specialised or managerial role.

Table - 1. Biographical Descriptive of Participants

\begin{tabular}{lllllllc}
\hline Code & Race & Gender & Age & Category & Company type & Environment & Years in profession \\
\hline WMM25 & White & Male & 25 & Mechanical & Mining & Production & 2.50 \\
WFP28 & White & Female & 28 & Process & Petrochemical & Project & 6.50 \\
WMP28 & White & Male & 28 & Process & Petrochemical & Project & 6.50 \\
IFE25 & Indian & Female & 25 & Electrical & Petrochemical & Project & 2.00 \\
BMM30 & Black & Male & 30 & Mechanical & Consulting & Project & 6.50 \\
WMI26 & White & Male & 26 & Industrial & Consulting & Project & 4.00 \\
\hline
\end{tabular}

\subsection{Data Collection}

In-depth interviewing was used as this allowed for the exploration, understanding and interpretation of the engineers' lived work experiences (Appleton, 1995; Kvale, 1996; Van Manen, 1990). Participants were asked to describe how they, as young engineers, experienced working for their company. The opening question was framed as: 'As an engineer, how do you experience working for this company - please tell me about some of the experiences you have had'. Further questions focussed on probing retention attitudes and experiences of engagement. Interviews were transcribed by a professional transcriber. Some participants responded to the interview questions in Afrikaans. The responses were translated to English by a qualified language practitioner. The request to participants to read and confirm the authenticity of the translated and transcribed responses were abided by all participants and all indicated agreement with the content as a true reflection of the interviews.

\subsection{Data analysis}

Data analysis was based on Ricoeur's (1976) phenomenological hermeneutical interpretation approach, also known as interpretive phenomenological analysis (Brocki \& Wearden, 2006). This involved the analytic steps of naïve reading, structural analysis and comprehensive understanding (Lindseth \& Norberg, 2004). Following these steps, each interview was read and analysed separately, first through a naïve reading and understanding of the text, followed by a thematic structural analysis and lastly a comprehensive understanding was formed of each interview. Once all the interviews were analysed thus, the three-step hermeneutic 
Socioeconomica - The Scientific Journal for Theory and Practice of Socio-economic Development 2016, 5(10): 153-170

process was replicated to ultimately gain a comprehensive understanding of the interview texts. Main themes and subthemes were constructed by making use of the hermeneutic circle principle, where the researcher moves back and forth from parts of the experience to the whole of the experience with the aim of increasing overall understanding of the texts (Annells, 1996). The researcher then formulated the final statement as a comprehensive understanding in everyday language and as close to the lived experience of the Generation $\mathrm{Y}$ engineers as possible (Lindseth \& Norberg, 2004) and with due consideration to a psychological interest (Smith, 2004) specifically that of work engagement.

\section{Findings}

The findings are discussed in line with the data analytic methodology followed, and commence with findings from the naïve reading of the data. The structural analysis is presented and the section concludes with a comprehensive understanding of generation $\mathrm{Y}$ engineers' retention and engagement behaviour.

\subsection{Naïve reading}

The initial naïve reading of each interview transcript and thereafter of the data set as a whole revealed that Generation Y engineers are motivated mostly by the nature of the project or task that they are doing. A sense of task engagement thus emerged. The participants' individualistic sense of value was demonstrated in how they were challenged and engaged by the task at hand and how they valued the experience they accumulated in the process of working on a project or a task. Relationships and connections with colleagues and mentors also seem to be a very strong motivational factor to the participants and they tend to find themselves committed to the people they work with, in addition to the project that they work on. The meaning and enjoyment derived from the task, was brought about by engaging in challenging projects, and cooperating with likeminded colleagues. Engagement to the organisation was thus expressed in terms of connections made with challenging tasks and with colleagues.

The data also demonstrated engineers' keen awareness of the benefits available to them and they expressed strong expectations in this regard from their employers. Participants' ascribed their turnover intentions to not having their expectations met and reflected a sense of entitlement with regard to certain benefits expected from the employer. Having their expectations met in terms of financial gain, getting promoted and work-life balance, functioned as a type of baseline retention factor. Having these baseline retention factors did not result in engagement, but rather functioned as retention factors keeping the engineer from leaving the company prematurely. Where engineers felt that they were not getting what they expect in terms of these retention factors, turnover seemed probable and engagement highly unlikely.

Despite having their expectations met, all the participants were either planning a shift in the focus of their current occupation, or a total change in occupation over time. The intention to 
leave the current employer seemed to be driven by personal objectives to become self-reliant and independent in their careers despite reporting strong levels of work satisfaction. Instances of career engagement were thus prevalent among the study participants. It seemed that instances of task engagement enticed the participants to stay at their companies, but as soon as career engagement became more important and their company could not provide the desired career engagement opportunities, they communicated turnover intentions either in the near or more distant future. Although task engagement was therefore essential to retention, for these Generation Y engineers, retention could not be ensured in light of potential career engagement.

\subsection{Structural analysis}

The structural analyses produced three predominant themes, namely hygiene retention factors, elements of work engagement and turnover intention.

\subsubsection{Hygiene retention factors}

Hygiene retention factors refer to the baseline occupational expectations of participants. Participants communicated expectations in terms of monetary reward, development and promotion opportunities, management support and work-life balance as requirements fundamental to their retention. Participants were frustrated and dissatisfied when these factors were not evident, yet for some the retention elements were in place and they were not necessarily motivated by them or engaged in their work as a result of them. Therefore, the retention factors were categorised under the theme hygiene retention factors congruent to Herzberg's (1987) theory of motivation and his distinction between hygiene factors and motivators. Participants, for example, expect equitable monetary rewards and promotional and developmental opportunities in relation to their self-perceived merit and level of performance. Participant WMP28 for instance explained monetary reward as a basic element of his employment contract: "This is my attitude toward money: Pay a guy enough so that money is off the table" and with regard to promotion IFE25 states: "People are not getting promoted. I am one of those people. It upsets $m e$ ". WMI26 focused on development and gaining experience as imperative to his retention: "If I'm not developing, if I feel I'm standing still, then I will consider moving". Development opportunities and gaining sought-after experience and exposure were emphasised as imperative in any employment choice.

WMP28 was especially upset about the lack of support he was receiving at work. He felt that he was not getting the management support he expected in terms of the work he was doing and considered leaving the company as a result: "In terms of engineering expertise, very little support, technical support, also very little, line management, very little support, business, very little support. It feels as if you are standing alone". WMP28 and IFE25 similarly ascribed their work dissatisfaction and their intention to leave the organisation, to management that could not be trusted. WMP28 for example said “At the moment I do not trust them, not at all. I can't trust 
Socioeconomica - The Scientific Journal for Theory and Practice of Socio-economic Development 2016, 5(10): 153-170

our management". Lastly work-life balance was viewed as a hygiene retention factor because participants indicated they made career decisions based on their families' needs, which were often prioritised above their work needs. Work-life balance was also important in that participants indicated that it was important to have time for other elements of life and not just work: "... half past four, five o'clock we just go on with our lives. If the work is done at the end of the day I continue with my life. It is very important" (BMM30).

\subsubsection{Elements of work engagement}

Different to the hygiene retention factors, the data elicited factors reflecting elements in the task and in the work-environment that impacted on participants' self-expressed sense of work engagement.

Responsible for and completing challenging, complex and meaningful tasks - Work engagement is enhanced by working with challenging and complex tasks. Participants highlighted being motivated strongly by the task; specifically, with its level of complexity, uniqueness, impact and meaningfulness. Participant WFP28 was for example inspired by working on ground-breaking technology, generating new solutions to a challenging project: " $M y$ goal is to ensure that the thing gets implemented. It really has a nationwide impact, it makes me very excited... it is totally a new technology; it is a first, a first in the world". Participants seemed to identify with challenging and complex tasks, deriving much satisfaction from being part of its completion "... and it is always exciting at the end of a project to look back and this is the changes that I made" (IFE25) and "I think what excites me is just successfully completing the task ... that is a good energiser for me" (BMM30). As such a sense of enthusiasm, inspiration, pride and challenge was evident when some of the participants spoke about feeling that they were making a meaningful contributing and having a real impact. Participant WMI26 expressed willingness to invest extra effort in his work by putting himself second, as he felt that they were creating something meaningful, which was greater than him.

Being part of a work group - Participants clearly communicated the importance of being part of a work group as essential in enjoying their work and remaining motivated in projects. Participants saw the people they worked with as an essential factor in deriving satisfaction from their jobs and their need to belong to the work group and establishing relationships in the work setting seemed highly valued: "what makes your environment mainly, is the people" (BMM30) and "I rub shoulders with guys who have really been in the game for a while" (WMI26).

Working in a flexible and autonomous work setting - Autonomy and freedom to organise one's time by having flexitime was also seen as significant in the engagement narrative. Participant WMI26 said that it was the most important thing for him, even more than the type of work that he did: "I have complete flexitime I can come in at $10 \mathrm{o}$ 'clock if I want to. The other evening I worked until one o'clock in the morning and that's fine. That is the first thing I enjoy". Some of the participants also showed willingness to invest extra effort in their work when they were able to organise their work setup according to their needs and wants. 


\subsubsection{Turnover intention}

Despite the hygiene retention factors and the elements of work-engagement, participants communicated short and longer term intentions to leave their companies. The long-term turnover intentions were mostly ascribed to the need to establish oneself as independent and selfreliant. Pursuing a career was deemed ultimately important rather than commitment or loyalty to an organisation or institution. Two participants (WMI26 and IFE25) showed enthusiasm about gaining sought-after experience and exposure by travelling overseas and being exposed to other cultures and work environments. It soon became clear that exposure and development was important to them predominantly because it provided them with unique expertise to, in comparison to others, become more sought-after and in demand. Such a unique skill set would assist them in establishing a career without needing the organisation. Self-reliance and independence seem to be foundational to career engagement and over the long term weighs stronger than organizational commitment: "I am fairly happy with what I am doing at the moment but over the long term I would like to be on my own... it's mainly that I wouldn't like to restrict myself to a specific business. It's more about being self-reliant. So for me it is very important that I feel I am at a state where I am self-reliant and can provide for myself not to be under an umbrella of another company or another person..." (BMM30).

Long-term turnover intention was thus implied in the context of pursuing an independent career as suggested by WMI26: "At 55 I want to retire and I want to teach teenagers. Yes, that's the career. I am really comfortable with that". As such the notion of career engagement emerged as the ultimate factor in retention behavior. (BMM30)

\subsection{Comprehensive understanding}

Generation $\mathrm{Y}$ engineers in this study demonstrated fundamental expectations that act as hygiene factors when it comes to retaining them. The organisation strongly risks losing these generation $\mathrm{Y}$ engineers should their work setting not provide them with equitably perceived financial rewards, promotion and developmental opportunities, management support as well as with a work structure that provides adequate work-life balance opportunity. Although these factors in the work setting do not necessarily elevate the work engagement experienced by these generation $\mathrm{Y}$ engineers, these factors are foundational to them being retained. In this regard retention and engagement become intertwined in the organisation as engagement cannot follow if retention is not secured. Yet retention cannot endure if engagement is not pursued. So following the foundational hygiene retention factors are the core elements of work engagement highlighted by the participants as including task engagement (through challenging and meaningful tasks), a relational and collaborative way of work and an autonomous and flexible work set up. It is therefore the nature of the task and the work setup that engages and motivates the participants, implying a focus on task engagement and work-set-up engagement rather than on organisational 
Socioeconomica - The Scientific Journal for Theory and Practice of Socio-economic Development 2016, 5(10): 153-170

commitment or engagement. Ultimately however career engagement seems to be most predominant in their future career planning as all the participants indicated a future intended career change towards establishing independent and self-reliant work.

The work engagement of generation $\mathrm{Y}$ engineers in this study is therefore constructed from a multiple level perspective, building from hygiene retention factors on a foundational level of engagement to different core elements of work engagement (task and work set-up) and ultimately to turnover intentions driven by career engagement. Such a comprehensive understanding of the retention and engagement behaviour of generation Y engineers in this study is depicted in Figure 1 below.

\section{Figure 1: A comprehensive understanding of Generation $Y$ Engineers retention and} engagement elements

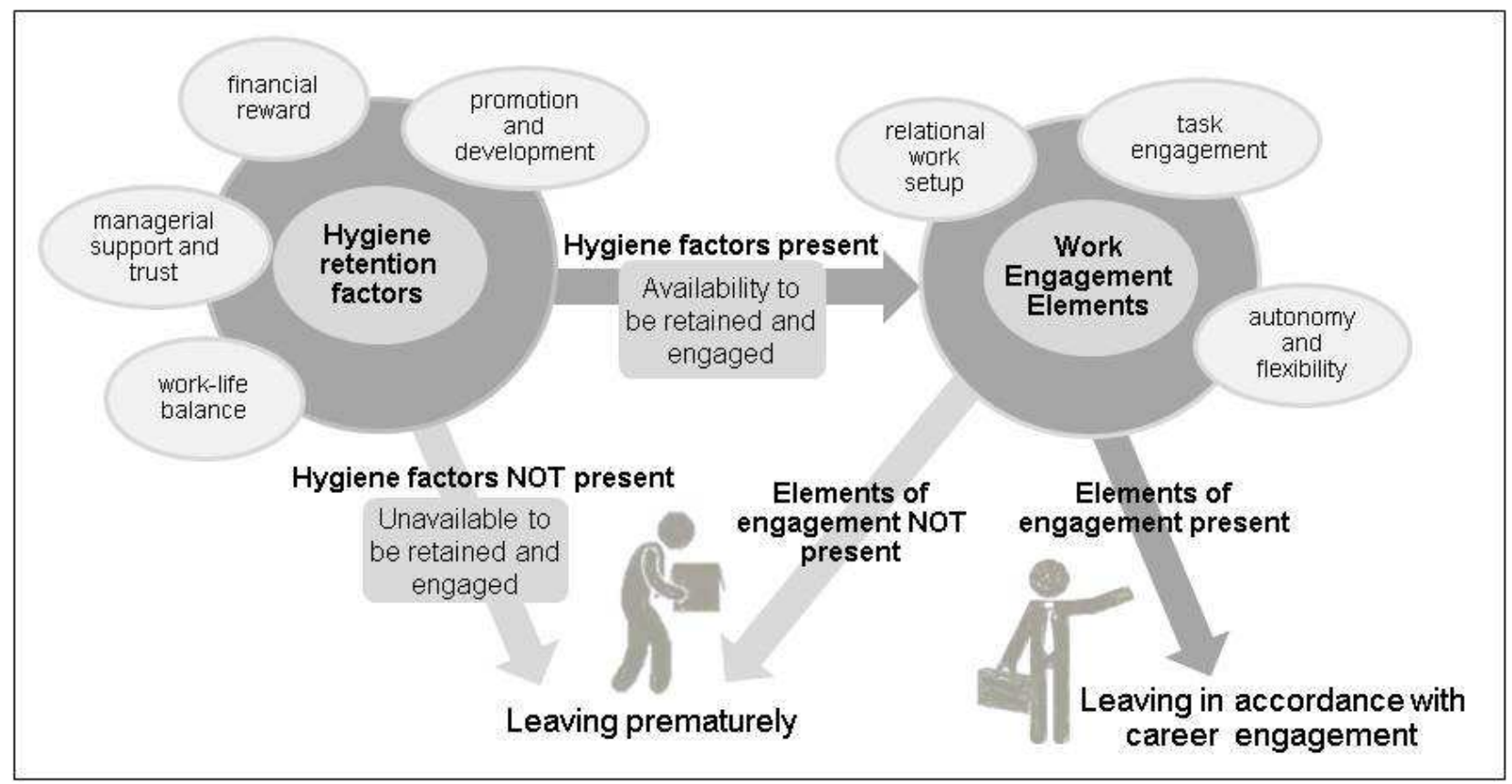

Source: Authors' work based on analysis and interpretation of results

\section{Discussion}

The purpose of this study was to explore the retention and work engagement of Generation Y engineers in a South African work context from a hermeneutic phenomenological stance. Different generations are said to form collective identities where distinct values, attitudes and expectations are contained within each cohort's identity (Bogdanowicz \& Bailey, 2002; Kowske et al., 2010; Sayers, 2007; Schuman \& Scott, 1989). This identity, which includes typical values, attitudes and expectations, is then brought into the workplace (Sayers, 2007; Zemke, 2001). The theory on work adjustment (TWA) (Bretz \& Judge, 1994) expound the 
consequences of person-job and person-organisation fit, on job satisfaction and tenure. From the perspective of the TWA, an employee's work identity interacts with factors in the job and in the organisation resulting in congruence/incongruence and consequently in satisfaction/ dissatisfaction which in turn impacts tenure and retention.

França, Sharp and Da Silva (2014) clearly distinguish between job satisfaction as a reactionary response to work identity needs having been met by the job/organisation and motivation as a forward looking emotional state which includes engagement as a core component. In the same vein, research among South African engineers by Stanz (2009) found the factors leading to their retention are not exactly the same as those leading to turnover. Our findings show that retention and engagement also do not denote the same meaning, yet the constructs are explicitly intertwined in their mutual effect on one another.

Hygiene retention factors identified in this study correlate with other findings, for example in terms of monetary reward (see Wright, 2007) promotion and development (Howe \& Nadler, 2009; Karlsson, 2008; Martins \& Martins, 2012; Petroulas, Brown \& Sundin, 2010; Van der Walt \& du Plessis, 2010; Vieira, 2010), managerial trust, support and communication (Irvine, 2010; Masibigiri \& Nienaber, 2011; Rahman, 2012), and work life balance opportunities (Gilbert, 2011; Vieira, 2010; Wright, 2007).

If companies do not provide employees with expected hygiene retention factors, Generation Y engineers may probably leave prematurely. Participants' willingness to leave their companies if hygiene retention factors are not present, could be ascribed to Generation Ys reporting higher levels of confidence, self-efficacy and an inflated sense of self than previous generations at the same age (Twenge \& Campbell, 2008). This, coupled with the fact that engineering skills are scarce and critical, may be the reason why these engineers feel that that they have many opportunities and are in a position to be 'picky' about where they work. The presence of hygiene retention factors provides the fundamental experience of psychological safety (see Kahn, 1990) and leads to general job satisfaction (França et al., 2014) because work identity needs are perceived to have been met. Motivation, defined as the desire to work and being engaged in work (França et al., 2014) is not necessarily consequent to job satisfaction, but from the perspective of the TWA, in a specific work setting job satisfaction is required for motivation to be maintained in that specific setting (Bretz \& Judge, 1994). By ensuring that hygiene retention factors are present, the organisation therefore establishes immediate retention but also creates the opportunity for engagement.

Having looked after hygiene retention factors for purposes of job satisfaction and immediate retention, the organisation should then also account for the identified elements of work engagement, to facilitate prolonged retention and enhance levels of work performance. Providing a work setting that facilitates work engagement is expected to lead to higher levels of performance (Malan, 2004). Three elements of work engagement emerged from the data namely task engagement, relational and collaborative way of work and an autonomous and flexible work setup. Task engagement as an element of work engagement surfaced from the data as characterised by challenging, complex and meaningful tasks. Similarly, challenging work 
Socioeconomica - The Scientific Journal for Theory and Practice of Socio-economic Development 2016, 5(10): 153-170

(Gilbert, 2011; Gruber, 2008; Karlsson, 2008), meaningful work (Van der Walt \& du Plessis, 2010; Vieira, 2010) and working on ground-breaking technology (Wright, 2007) has been found to indicate task or work characteristics that facilitate generation $\mathrm{Y}$ engineers work engagement. Task identity is important to Generation Y engineers as it correlates significantly with higher levels of performance (Onukwube \& Iyagba, 2011). Identifying the importance of relationships for engineers as an element of work engagement is also supported in other studies (Gruber, 2008; Myers \& Sadaghiani 2010) and having autonomy and freedom to organise one's work setup, confirms similar findings by Gruber (2008), Lieber (2010) and Puybaraud (2010).

In this study elements of engagement were therefore not found in terms of work-related engagement (Schaufeli \& Bakker, 2004) but in terms of instances of task engagement, worksetup engagement and career engagement. Although retention can thus be prolonged through task and work set-up engagement, retention of Generation $\mathrm{Y}$ engineers can ultimately not be expected as a definite, as these workers intend to leave the organisation in line with their career engagement needs. Career engagement is grounded in the affective and cognitive connection to one's career and it is demonstrated through being focused on and energised by proactive behaviours related to the development of one's career (Hirschi \& Freund, 2014; Pickerell, 2013).

If generation $\mathrm{Y}$ engineers are going to leave anyway, this then begs the question what organisations can do to maintain retention as long as possible. Figure 2 depicts the presence of hygiene retention factors in a matrix with the presence of elements of engagement providing a guide for organisations in terms of the intervention focus required to prolong generation $\mathrm{Y}$ employees' retention. When hygiene retention factors are strongly present, but elements of engagement weak (quadrant A), employees will be satisfied but not motivated (compare França et al., 2014). In this regard the organisation should focus on engaging employees in challenging and meaningful projects, provide the opportunity to collaborate and establish relationships at work and set up the work context to allow flexibility and anonymity. In quadrant B, the elements of work engagement are high, but the hygiene retention factors low. Task engagement and work set-up engagement may therefore be in place, but the organisation should guard against employee dissatisfaction by ensuring equitable monetary reward, promotion and development opportunities, managerial support and work-life balance initiatives. Ultimately, when both hygiene retention factors and elements of engagement have been looked after, Generation Y employees will find themselves satisfied and engaged with the task and work-set up, but may still opt to leave due to pursuing career engagement elsewhere (Quadrant C). The organisation should craft innovative alternatives to retain generation $\mathrm{Y}$ employees such as, for example, establishing associate contracts, or independent consulting contracts. 
Figure 2: Matrix: hygiene retention factors and elements of work engagement

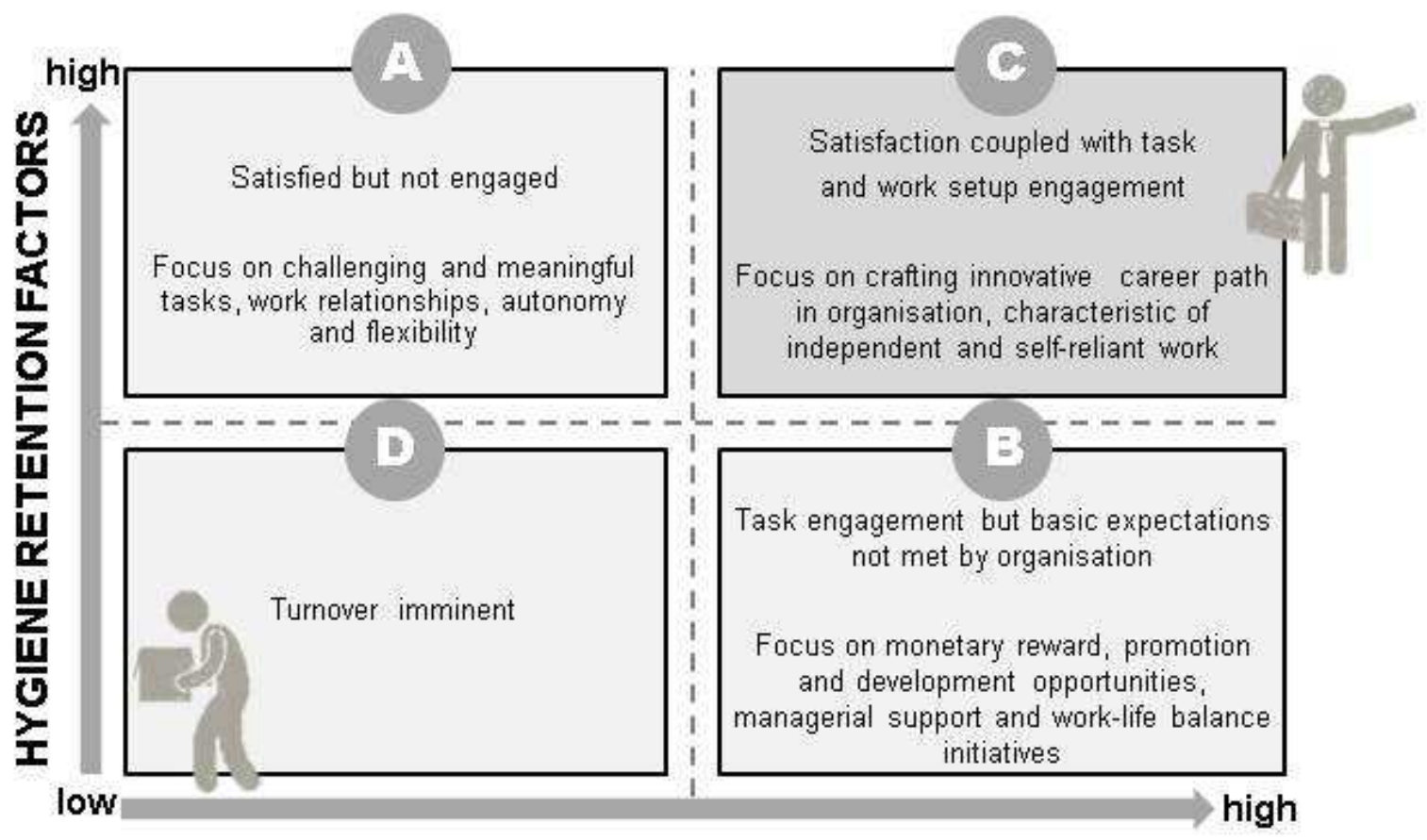

ELEMENTS OF ENGAGEMENT

Source: Authors' work based on analysis and interpretation of results

\section{Conclusion}

The study did not include all engineering categories and race groups in South Africa and the findings cannot be generalised due to its contextual focus and small sample. The intention of the study was however not to generalise, but to gain an in-depth understanding of the retention and engagement behaviour of generation $\mathrm{Y}$ engineers.

The results showed that for Generation Y engineers working in the South African context, being retained and being engaged are interlinked. Participants first need to feel psychologically safe by determining that they are getting what they expect in terms of a number of hygiene retention factors before they can make themselves available by staying with the organisation and potentially being engaged. Certain elements of their task and their work setup engage them and cause them to stay at the company even longer in the expectation of experiencing more instances of engagement. However, in the absence of engagement or when career engagement is pursued external to the organisation, this could propel them to leave. Organisations should build on their focus on task and work-set up engagement by focussing on career engagement and craft innovative pathways within the organisation to accommodate generation Y's independence and self-reliance in pursuing a career. 
Socioeconomica - The Scientific Journal for Theory and Practice of Socio-economic Development

2016, 5(10): 153-170

\section{References}

Allen, D.G., Bryant, P.C., \& Vardaman, J.M. (2010). Retaining talent: Replacing misconceptions with evidence-based strategies. Academy of Management Perspectives, 24(2), 48-64. doi.org/10.5465\%2FAMP.2010.51827775

Annells, M. (1996). Hermeneutic phenomenology: Philosophical perspectives and current use in nursing research. Journal of Advanced Nursing, 23(4), 705-713. doi.org/10.1111\%2Fj.1365-2648.1996.tb00041.x

Anthony-McMann, P. E., Ellinger, A. D., Astakhova, M., \& Halbesleben, J. R. (2016). Exploring different operationalizations of employee engagement and their relationships with workplace stress and burnout. Human Resource Development Quarterly, published online. Available at: doi.org/10.1002/hrdq.21276. [Accessed 15 February 2016].

Appleton, J.N. (1995). Analysing qualitative interview data: Addressing issues of validity and reliability. Journal of Advanced Nursing, 22(5), 993-997. doi.org.oasis.unisa.ac.za/10.1111/j.1365-2648.1995.tb02653.x

Arthur, M.B., Khapova, S.N., \& Wilderom, C.P.M. (2005). Career success in a boundaryless career world. Journal of Organizational Behavior, 26(2), 177-202. doi.org/10.1002\%2Fjob.290

Aruna, M., \& Anitha, J. (2015). Employee retention enablers: Generation Y employees. SCMS Journal of Indian Management, 12(3), 94-103.

Bakker, A.B., Albrecht, S.L., \& Leiter, M.P. (2011). Work engagement: Further reflections on the state of play. European Journal of Work and Organizational Psychology, 20(1), 7488. doi.org/10.1080\%2F1359432X.2010.546711

Bakker, A.B., \& Bal, P. M. (2010). Weekly work engagement and performance: A study among starting teachers. Journal of Occupational and Organizational Psychology, 83(1), 189206. doi.org/10.1348\%2F096317909X402596

Bakker, A.B., Demerouti, E., \& Schaufeli, W.B. (2003). Dual processes at work in a call centre: An application of the job demands-resources model. European Journal of Work and Organizational Psychology, 12, 393-417. doi.org/10.1080\%2F13594320344000165

Bakker, A.B., \& Schaufeli, W.B. (2008). Positive organizational behavior: Engaged employees in flourishing organizations. Journal of Organizational Behavior, 29(2), 147-154. doi.org/10.1002\%2Fjob.515

Bakker, A.B., Schaufeli, W.B., Leiter, M.P., \& Taris, T.W. (2008). Work engagement: An emerging concept in occupational health psychology. Work \& Stress: An International Journal of Work, Health \& Organisations, 22(3), 187-200. doi.org/10.1080\%2F02678370802393649

Bogdanowicz, M.S., \& Bailey, E.K. (2002). The value of knowledge and the values of the new knowledge worker: Generation X in the new economy. Journal of European Industrial Training, 26(2-4), 125-129. doi.org/10.1108\%2F03090590210422003 
Bretz, R.D., \& Judge, D.A. (1994). Person-organisation fit and the theory of work adjustment: implications for satisfaction, tenure and work success. Journal of Vocational behavior, 44(1), 32-54.

Brocki, J.M., \& Wearden, A.J. (2006). A critical evaluation of the useof interpretative phenomenological analysis (IPA) in health psychology. Psychology \& Health, 21(1), 87108, DOI:10.1080/14768320500230185

Burnett, J. (2011). Generations: The Time Machine in Theory and Practice.

Constanza, D.P., Badger, J.M., Fraser, R.L., Severt, J.B., \& Gade, P.A. (2012). Generational differences in work-related attitudes: A meta-analysis. Journal of Business Psychology, 27(4), 375-394. doi.org/10.1007\%2Fs10869-012-9259-4

Consulting Engineers South Africa. (2012). Biannual Economic and Capacity Survey: July to December 2011. Retrieved from http://www.cesa.co.za/sites/default/files/CESA_BECS_Report_Jun12_Final.pdf

Dahlberg, K., Dahlberg, H. \& Nyström, M. (2007). Reflective lifeworld research. (2 ${ }^{\text {nd }}$ Ed.). Lund: Student Litteratur.

Department for Higher Education and Training. (n.d). Skills demand list 2012-2013. http://www.dhet.gov.za/LinkClick.aspx?fileticket=akZ2tL6YU7k=\&tabid=346\&mid=14 $\underline{15}$

Department of Home Affairs (2009, May 25). Government notice. Government Gazette, 527(32261), 3-9. Available online: http://imcosa.co.za/images/stories/downloads/quota\%20list\%202009.pdf. [Accessed 12 November 2016]

Deal, J.J., Stawiski, S., Graves, L.M., Gentry, W.A., Ruderman, M., \& Weber, T.J. (2012). Perceptions of authority and leadership: A cross-national, cross-generational investigation. In E.S. Ng, S.T. Lyons \& L. Schweitzer (Eds.), Managing the new workforce: International perspectives on the millennial generation (pp.152-180). Cheltenham, UK: Edward.

Deloitte. (2009). State of the media democracy survey (3rd ed.). Retrieved from http://www.deloitte.com/us/realitycheck

Du Plooy, J., \& Roodt, G. (2010). Work engagement, burnout and related constructs as predictors of turnover intentions. SA Journal of Industrial Psychology, 36(1), Art.\#910. doi.org/10.4102\%2Fsajip.v36i1.910

Durrheim, K. (2007). Research design. In M. Terre Blance, K. Durrheim, \& D. Painter (Eds.), Research in practice: Applied methods for the social sciences (2nd edn.) (pp. 33-59). Cape Town, South Africa: University of Cape Town.

França, C., Sharp, H., \& Da Silva, F. Q. (2014, September). Motivated software engineers are engaged and focused, while satisfied ones are happy. In Proceedings of the 8th ACM/IEEE International Symposium on Empirical Software Engineering and Measurement (p. 32). ACM. 
Socioeconomica - The Scientific Journal for Theory and Practice of Socio-economic Development 2016, 5(10): 153-170

Feldman, D.C., \& Ng, T.W.H. (2007). Careers: Mobility, embeddedness, and success. Journal of Management, 33(3), 350-376. doi.org/10.1177\%2F0149206307300815

Gilbert, J. (2011). The millennials: A new generation of employees, a new set of engagement policies. Ivey Business Journal, 75(5), 26-28. Retrieved from http://0search.ebscohost.com.oasis.unisa.ac.za/login.aspx ?direct=true \&db=bth\&AN=66293927 \&scope $=$ site

Gruber, A. (2008). Factors that affect the retention of engineers in the contracting sector in South Africa. (Unpublished doctoral thesis, University of Johannesburg).

Harter, J.K., Schmidt, F.L., \& Hayes, T.L. (2002). Business-unit-level relationship between employee satisfaction, employee engagement, and business outcomes: A meta-analysis. Journal of Applied Psychology 87(2), 268-279. doi.org/10.1037\%2F\%2F0021$\underline{9010.87 .2 .268}$

Health Professions Act 56 of 1974. Ethical rules of conduct for practitioners registered under the Health Professions Act, No. R. 717 Form 223. Government Gazette (No. 29079). Retrieved from http://www.hpcsa.co.za/downloads/conduct ethics/rules/ethical rules psychology.pdf

Hershatter, A., \& Epstein, M. (2010). Millennials and the world of work: An organization and management perspective. Journal of Business Psychology, 25(2), 211-223. doi.org/10.1007\%2Fs10869-010-9160-y

Herzberg, F., 1987. One more time: how do you motivate employees? Harvard business review, 65(5), Reprint number: 87506.

Howe, N., \& Nadler, R. (2009, November/ December). They're back. Talking Stick, 27(2), 1618. Retrieved from http://www.nxtbook.com/nxtbooks/acuho/talkingstick_20091112/\#/2

Hillman, D.R. (2014). Understanding multigenerational work-value conflict resolution. Journal of Workplace Behavioral Health, 29(3), 240-257. doi.org/10.1080/15555240.2014.933961

Hirschi, A., \& Freund, P. A. (2014). Career engagement: Investigating intraindividual predictors of weekly fluctuations in proactive career behaviors. The Career Development Quarterly, 62(1), 5-20.

Irvine, D. (2010). How to reward a multigenerational and culturally diverse workforce. Workspan, 4(10), 63-68. Retrieved from http://www.worldatwork.org/waw/adimLink?id=36840

Jones, C., \& Czerniewicz, L. (2010). Describing or debunking? The net generation and digital natives. Journal of Computer Assisted Learning, 26(5), 317-320, doi.org/10.1111\%2Fj.1365-2729.2010.00379.x

Joshi, A., Dencker, J.C., \& Franz, G. (2011). Generations in organisations. Research in Organizational Behavior, 31, 177-205. doi.org/10.1016/j.riob.2011.10.002

Khapova, S.N. (2006). Careers in the knowledge economy and web-based career support: New challenges and opportunities. (Doctoral dissertation, University of Twente, Enschede, Netherlands). Retrieved from http://doc.utwente.nl/57123/1/thesis_Khapova.pdf 
Miehe Marais, E. et al.

Retention and Engagement of Generation $Y$ Engineers

Karlsson, J. (2008). Should I stay or should I go? Turnover among young engineers. (Masters' thesis, Malardalen University, Vasteras, Sweden). Retrieved from http://urn.kb.se/resolve?urn=urn:nbn:se:mdh:diva-970

Kennedy, E., \& Daim, T.U. (2010). A strategy to assist management in workforce engagement and employee retention in the high tech engineering environment. Evaluation and Program Planning, 33(4), 468-476. doi.org/10.1016\%2Fj.evalprogplan.2009.12.001

Kowske, B.J., Rasch, R., \& Wiley, J. (2010). Millennials' (lack of) attitude problem: An empirical examination of generational effects on work attitudes. Journal of Business Psychology, 25(2), 265-279. doi.org/10.1007\%2Fs10869-010-9171-8

Kultalahti, S. \& Viitala, R. L. (2014). Sufficient challenges and a weekend ahead-Generation Y describing motivation at work. Journal of Organizational Change Management,27(1), 569- 582. http://dx.doi.org/10.1108/JOCM-05-2014-0101

Kvale, S. (1996). InterViews: An introduction to qualitative research. Thousand Oaks, CA: Sage. Lieber, L.D. (2010). How HR can assist in managing the four generations in today's workplace. Employment Relations Today, 36(4), 85-91. doi.org/10.1002\%2Fert.20278

Lindseth, A., \& Norberg, A. (2004). A phenomenological hermeneutical method for researching lived experience. Scandinavian Journal of Caring Sciences, 18(2), 145-153. doi.org/10.1111\%2Fj.1471-6712.2004.00258.x

Mannheim, K. (1952). The problem of generations. In K. Mannheim (Ed.), Essays on the sociology of knowledge (pp. 276-322). London, England: Routledge. (Original work published 1928).

Masibigiri, V., \& Nienaber, H. (2011). Factors affecting the retention of Generation X public servants: An exploratory study. SA Journal of Human Resource Management, 9(1), 4454. doi.org/10.4102\%2Fsajhrm.v27i4.318

Martins, N., \& Martins, E. (2012).Assessing millennials in the South African work context. In E.S. Ng, S.T. Lyons \& L. Schweitzer (Eds.), Managing the new workforce: International perspectives on the millennial generation (pp.152-180). Cheltenham, England: Edward.

Moss, M., \& Martins, N. (2014). Generational sub-cultures: Generation Y a sub-culture? Mediterranean Journal of Social Sciences, 5(21), 147-160.

Myers, K.K., \& Sadaghiani, K. (2010). Millennials in the workplace: A communication perspective on millennials' organizational relationships and performance. Journal of Business Psychology, 25(2), 225-238. doi.org/10.1007\%2Fs10869-010-9172-7

Neault, R. A., \& Pickerell, D. A. (2011). Career engagement: Bridging career counselling and employee engagement. Journal of Employment Counselling, 48(4), 185-189.

Nash, L. (1978). Concepts of existence: Greek origins of generational thought. Daedalus, 107(4), 1-21. Retrieved from http://0www.jstor.org.oasis.unisa.ac.za/stable/pdfplus/2083201.pdf?acceptTC $=$ true

National Planning Commission. (2011). A diagnostic overview. Retrieved from http://www.info.gov.za/view/DownloadFileAction?id=147192 
Socioeconomica - The Scientific Journal for Theory and Practice of Socio-economic Development 2016, 5(10): 153-170

Onukwube, H.N., \& Iyagba, R. (2011). Construction professionals job performance and characteristics: A comparison of indigenous and expatriate construction companies in Nigeria. Australasian Journal of Construction Economics and Building, 11(2), 71-83. Retrieved from http://epress.lib.uts.edu.au/journals/index.php/AJCEB/article/viewFile/1817/2344

Park, J., \& D. Gursoy. (2012). Generation effects on work engagement among U.S. hotel employees. International Journal of Hospitality Management, 31(4), 1195-1202. doi.org/10.1016\%2Fj.ijhm.2012.02.007

Papenhausen, C. (2011). A generational explanation for surges in managerial rhetorics. Management Research Review, 34(10), 1078 - 1086. doi:10.1108/01409171111171483

Petroulas, E., Brown, D., \& Sundin, H. (2010). Generational characteristics and their impact on preference for management control systems. Australian Accounting Review, 20(3), 221240. doi.org/10.1111\%2Fj.1835-2561.2010.00099.x

Pickerell, D. A. (2013). Examining the career engagement of Canadian career development practitioners. Unpublished Doctoral dissertation. Fielding Graduate University.

PriceWaterhouseCoopers. (2009). Managing tomorrow's people [Research report]. Retrieved from http://www.pwc.com/gx/en/managing-tomorrows-people/future-of-work/pdf/mtphow-the-downturn.pdf

Puybaraud, M. (2010). Generation Y and the workplace, Annual Report 2010 [Research report]. Retrieved from http://www.haworth.it/it/content/download/8985/545554/file/OxygenzReport_2010_EN.pdf

Rahman, R.H.A. (2012). Malaysian firms' role in retaining engineers. The Economic and Labour Relations Review, 23 (4), 57-78. doi.org/10.1177\%2F103530461202300405

Ricoeur, P. (1976). Interpretation theory: Discourse and the surplus of meaning. Fort Worth, TX: Texas Christian University Press.

Robyn, A.M. (2012). Intention to quit amongst Generation $Y$ academics at higher education institution. (Masters' dissertation, University of Stellenbosch, Stellenbosch, South Africa). Retrieved from http://scholar.sun.ac.za/handle/10019.1/71603

Robyn, A., \& Du Preez, R. (2013). Intention to quit amongst Generation Y academics in higher education. SA Journal of Industrial Psychology/SA Tydskrif vir Bedryfsielkunde, 39(1), Art. \#1106, 14 pages. http://dx.doi.org/10.4102/ sajip.v39i1.1106

Rose, D.M., \& Gordon, R. (2010). Retention practices for engineering and technical professionals in an Australian public agency. The Australian Journal of Public Administration, 69(3), 314-325. doi.org/10.1111\%2Fj.1467-8500.2010.00693.x

Rosow, I. (1978). What is a cohort and why? Human Development, 21(2), 65-75. doi.org/10.1159\%2F000271575

Rothmann, S., \& Rothmann Jr, S. (2010). Factors associated with employee engagement in South Africa. SA Journal of Industrial Psychology, 36(2), Art.\#925. doi.org/10.4102\%2Fsajip.v36i2.925 
Ryder, N. (1965). The cohort as a concept in the study of social change. American Sociological Review, 30(6), 843-861. doi.org/10.2307\%2F2090964

Saks, A. M. (2006). Antecedents and consequences of employee engagement. Journal of Managerial Psychology, 21(7), 600-619. doi.org/10.1108\%2F02683940610690169

Sayers, R. (2007). The right staff from x to y. Library Management, 28(8/9), 474-487. doi.org/10.1108\%2F01435120710837765

Simpson, M.R. (2009). Engagement at work: A review of the literature. International Journal of Nursing Studies, 46(7), 1012-1024. doi.org/10.1016\%2Fj.ijnurstu.2008.05.003

Schaufeli, W.B., \& Bakker, A.B. (2004). Job demands, job resources and their relationship with burnout and engagement: A multi-sample study. Journal of Organisational Behavior, 25(3), 293-315. doi.org/10.1002\%2Fjob.248

Schaufeli, W.B., \& Bakker, A.B. (2010). Defining and measuring work engagement: Bringing clarity to the concept. In A. B. Bakker \& M. P. Leiter (Eds.), Work engagement: A handbook of essential theory and research (pp. 10-24). New York: Psychology Press.

Schuler, S.R., \& Jackson, S.C. (2006). Managing Human Resources. Cengage Learning.

Schuman, H., \& Scott, J. (1989). Generations and collective memories. American Sociological Review, 54 (3), 359-381. doi.org/10.2307\%2F2095611

Smith, J. A. (2004). Reflecting on the development of interpretative phenomenological analysis and its contribution to qualitative research in psychology. Qualitative Research in Psychology, 1, 39-54.

Stanz, K. (2009, September). Factors affecting employee retention: What do engineers think? Management today, 17-19. Retrieved from http://hdl.handle.net/2263/12199

Sutherland, M., \& Jordaan, W. (2004). Factors affecting the retention of knowledge workers. $S A$ Journal of Human Resource Management, 2 (2), 55-64. doi.org/10.4102\%2Fsajhrm.v2i2.39

Talent Edge 2020. (2011). Building the recovery together - What talent expects and how leaders are responding [Research report]. Retrieved from http://www.deloitte.com/assets/DcomUnitedStates/Local\%20Assets/Documents/IMOs/Talent/us_talent_talentedge2020employ ee_042811.pdf

Twenge, J.M., \& Campbell, W.K. (2008). Increases in positive self-views among high school students: Birth cohort changes and anticipated performance, self-satisfaction, self-liking and self-competence. Psychological Science, 19(11), 1082-6. doi.org/10.1111\%2Fj.14679280.2008.02204.X

UNESCO (2010). Engineering: issues, challenges and opportunities for development. Paris: UNESCO.

Van der Walt, S., \& Du Plessis, T. (2010). Leveraging multi-generational workforce values in interactive information societies.SA Journal of Information Management, 12(1), Art. \#441. doi.org/10.4102\%2Fsajim.v12i1.441

Van Manen, M. (1990). Researching lived experience. Albany, NY: The State University of New York. 
Socioeconomica - The Scientific Journal for Theory and Practice of Socio-economic Development 2016, 5(10): 153-170

Van Schalkwyk, S., Du Toit, D.H., Bothma, A.S., \& Rothmann, S. (2010). Job insecurity, leadership empowerment behaviour, employee engagement and intention to leave in a petrochemical laboratory. SA Journal of Human Resource Management, 8(1), Art.\#234. doi.10.4102/sajhrm.v8i1.234

Vieira, J. (2010). Early career expectations and retention factors of Generation Y engineers. (Masters' dissertation, University of Johannesburg, Johannesburg, South Africa). Retrieved from https://ujdigispace.uj.ac.za/handle/10210/4911

Wright, A. (2007). The effect of diversity targeting on the motivation and retention of white technical graduates in a large South African corporation. (Masters' dissertation, University of Pretoria, Pretoria, South Africa). Retrieved from http://upetd.up.ac.za/thesis/available/etd-03282010-122847/unrestricted/dissertation.pdf

Zemke, R. (2001). Here come the millennials. Training, 38(7), 44-9. Retrieved from http://www.eric.ed.gov/ERICWebPortal/search/detailmini.jsp?_nfpb=true\&_\&ERICExtS earch_SearchValue_0=EJ629017\&ERICExtSearch_SearchType_0=no\&accno=EJ62901 I 
Copyright of Socioeconomica is the property of Scientific Society Akroasis and its content may not be copied or emailed to multiple sites or posted to a listserv without the copyright holder's express written permission. However, users may print, download, or email articles for individual use. 